\title{
Muscarinic Receptor Regulation of Osmosensitive Taurine Transport in Human SH-SY5Y Neuroblastoma Cells
}

\author{
Daniel J. Foster, Victor M. Vitvitsky, Ruma Banerjee, Anne M. Heacock, and Stephen K. \\ Fisher \\ Molecular and Behavioral Neuroscience Institute (AMH, SKF) and Departments of Biological \\ Chemistry (RB, VVM) and Pharmacology (DJF, SKF), University of Michigan, Ann Arbor, \\ Michigan.
}

\begin{abstract}
The ability of G-protein-coupled receptors to regulate osmosensitive uptake of the organic osmolyte, taurine, into human SH-SY5Y neuroblastoma cells has been examined. When monitored under isotonic conditions and in the presence of physiologically relevant taurine concentrations $(1-100 \mu \mathrm{M})$, taurine influx was mediated exclusively by a $\mathrm{Na}^{+}$-dependent, highaffinity $\left(K_{\mathrm{m}}=2.5 \mu \mathrm{M}\right)$ saturable transport mechanism $\left(V_{\max }=0.087 \mathrm{nmol} / \mathrm{mg}\right.$ protein $\left./ \mathrm{min}\right)$. Reductions in osmolarity of $>20 \%$ (attained under conditions of a constant $\mathrm{NaCl}$ concentration) resulted in an inhibition of taurine influx ( $>30 \%$ ) that could be attributed to a reduction in $V_{\max }$, whereas the $K_{\mathrm{m}}$ for uptake remained unchanged. Inclusion of the muscarinic cholinergic agonist, oxotremorine-M (Oxo-M), also resulted in an attenuation of taurine influx $\left(\mathrm{EC}_{50} \sim 0.7 \mu \mathrm{M}\right)$. Although Oxo-M-mediated inhibition of taurine uptake could be observed under isotonic conditions ( 25-30\%), the magnitude of inhibition was significantly enhanced by hypotonicity $(\sim 55-60 \%)$, a result that also reflected a reduction in the $V_{\max }$, but not the $K_{\mathrm{m}}$, for taurine transport. Oxo-M-mediated inhibition of taurine uptake was dependent upon the availability of extracellular $\mathrm{Ca}^{2+}$ but was independent of protein kinase $\mathrm{C}$ activity. In addition to Oxo-M, inclusion of either thrombin or sphingosine 1-phosphate also attenuated volume-dependent taurine uptake. The ability of Oxo-M to inhibit the influx of taurine was attenuated by 4-[(2-butyl-6,7dichloro-2-cyclopentyl-2,3-dihydro-1-oxo-1H-inden-5-yl)oxy]butanoic acid (DCPIB), an inhibitor of the volume-sensitive organic osmolyte and anion channel. DCPIB also prevented receptormediated changes in the efflux and influx of $\mathrm{K}^{+}$under hypoosmotic conditions. The results suggest that muscarinic receptor activation can regulate both the volume-dependent efflux and uptake of taurine and that these events may be functionally coupled.
\end{abstract}

\section{Keywords}

Taurine transporter; volume regulation; hyponatremia; organic osmolytes; muscarinic cholinergic receptor; volume-sensitive organic osmolyte and anion channel

\section{Introduction}

When exposed to hypoosmotic stress, cells initially swell in proportion to the reduction in osmolarity and then normalize their volume via a process known as regulatory volume decrease. The latter involves the release of osmolytes, both inorganic $\left(\mathrm{K}^{+}, \mathrm{Cl}^{-}\right)$and organic

Corresponding author: Dr. Stephen K. Fisher, Molecular and Behavioral Neuroscience Institute, University of Michigan, 5039 Biomedical Science Research Building, Ann Arbor, MI 48109-2200, skfisher@ umich.edu. Telephone: (734)-763-4376; Fax: (734)-936-2690. 
(amino acids, polyols and methylamines) and the exit of obligated water (McManus et al. 1995). Although inorganic osmolytes constitute the quantitatively major fraction of the osmolyte pool (60-65\%; Pasantes-Morales et al. 2002), large changes in ion concentration can adversely impact cell excitability. Thus the pool of "non-perturbing" organic osmolytes plays a pivotal role in countering changes in osmolarity without compromising cell function. One of the most quantitatively important organic osmolytes in the CNS is the sulfur amino acid, taurine (Huxtable 1992; Miller et al. 2000; Lambert 2004). In response to hypoosmolarity, taurine is primarily released from neural cells via a volume-sensitive organic osmolyte and anion channel (VSOAC), although the involvement of additional channels cannot be discounted (Shennan 2008). VSOAC, which has been extensively characterized both electrophysiologically and pharmacologically, is selectively permeable to anions (primarily $\mathrm{Cl}^{-}$) and organic osmolytes. However, despite intensive efforts, the molecular identity of VSOAC remains unknown (for review, see Okada 2006).

The most common cause of hypoosmotic swelling is a condition known as hyponatremia, which is defined as a reduction in serum $\mathrm{Na}^{+}$concentration below a normal value of 145 to $136 \mathrm{mEq} / \mathrm{L}$. In severe cases of hyponatremia, serum $\mathrm{Na}^{+}$concentrations of $<110 \mathrm{mEq} / \mathrm{L}$ have been reported, which represent a reduction in plasma osmolarity of $\sim 25 \%$ (Haussinger et al. 1994). Hyponatremia is the most commonly encountered electrolyte disorder in clinical practice and is conservatively estimated to occur in $2.5-5.0 \%$ of hospitalized patients, with the young and elderly disproportionately affected (Bhardwaj 2006; Lien and Shapiro 2007). The majority of symptoms associated with hyponatremia are neurological in origin and these include nausea, headache, coma and respiratory arrest. Reductions in the concentrations of brain organic osmolytes during hyponatremia can be quite dramatic. Thus, when animals are rendered chronically hyponatremic, substantial losses of the major organic osmolytes (taurine, glutamate and myo-inositol) from the CNS are observed with taurine being the most severely impacted (70-90\% reductions; Lien et al. 1991; Pasantes-Morales et al. 2002; Massieu et al. 2004).

The volume-dependent efflux of taurine from a variety of neural preparations in response to hypoosmolarity has been extensively documented. In addition, the magnitude of osmosensitive taurine release may be further enhanced following the activation of specific GPCRs (for review, see Fisher et al. 2008). However, it is less clear whether the uptake of taurine, which, under physiologically relevant concentrations, is mediated primarily via a $\mathrm{Na}^{+}$-dependent, high-affinity transport system (TauT), is also subject to such regulation. For example, whereas high affinity taurine transport is reported to be unaffected by a reduction in osmolarity in either astrocytes or cerebellar granule cells (Sanchez-Olea et al. 1991; Schousboe et al. 1991), a recent study indicated that taurine uptake into rat hippocampal neurons was significantly attenuated in response to a reduction in osmolarity (Olson and Martinho 2006a). A volume-dependent regulation of osmolyte uptake could potentially have a significant impact on osmolyte homeostasis since the net loss of an osmolyte from a hypoosmotically stressed cell would reflect not only its efflux, but also its re-uptake. In this context, we recently observed that under hypoosmotic conditions, the activation of specific GPCRs on human SH-SY5Y neuroblastoma cells resulted not only in an increase in the efflux of $\mathrm{K}^{+}$(monitored as ${ }^{86} \mathrm{Rb}^{+}$), but also in its influx (Foster et al. 2008). These opposing effects serve to minimize the loss of $\mathrm{K}^{+}$from hypoosmotically-stressed cells. In the present study, we have examined the possibility that taurine uptake into SH-SY5Y cells may also be subject to regulation by osmolarity and receptor activation. The results indicate that, in contrast to the situation pertaining to $\mathrm{K}^{+}$influx, hypoosmolarity attenuates the high affinity uptake of taurine into these cells and that receptor activation elicits a further inhibition of transport. Inhibition of taurine uptake could be largely prevented when osmosensitive taurine efflux was blocked by inclusion of DCPIB, an inhibitor of VSOAC. Thus under conditions of hypotonicity, activation of GPCRs on SH-SY5Y cells elicits both a facilitation 
of taurine efflux and an attenuation of taurine uptake, regulatory events which act in concert to enhance the loss of the osmolyte from cells.

\section{Materials and Methods}

\section{Materials}

[1,2- $\left.{ }^{3} \mathrm{H}\right]$ Taurine $(1.15 \mathrm{TBq} / \mathrm{mmol})$ and myo-[2- $\left.{ }^{3} \mathrm{H}\right]$ inositol $\left.2.4 \mathrm{TBq} / \mathrm{mmol}\right)$ was obtained from GE Healthcare (Chalfont St. Giles, UK). Rubidium chloride ( ${ }^{86} \mathrm{Rb}^{+}$-labeled: $\left.37 \mathrm{GBq} / \mathrm{g}\right)$ was obtained from PerkinElmer Life and Analytical Sciences (Waltham, MA).

Oxotremorine-M, sphingosine 1-phosphate, thrombin, PMA, $\beta$-alanine, hypotaurine and atropine were purchased from Sigma-Aldrich (St. Louis, MO). Guanidinethyl sulfonate was purchased from Toronto Chemicals (Toronto, ON). DCPIB was obtained from Tocris Bioscience, Inc. (Ellisville, MO). Thapsigargin, Ro-31-8220, Gö 6983 and bisindolylmaleimide 1 (BIM) were obtained from Calbiochem (San Diego, CA). Dulbecco's modified Eagle medium (DMEM) and 50× penicillin/streptomycin were obtained from Invitrogen (Carlsbad, CA). Fetal calf serum was obtained from Lonza Walkersville, Inc. (Walkersville, MD). Tissue culture supplies were obtained from Corning Inc. (Corning, NY), Starstedt (Newton, NC) and BD BioSciences (San Jose, CA). Universol was obtained from MP Biomedicals (Solon, $\mathrm{OH}$ ).

\section{Cell Culture}

Human SH-SY5Y neuroblastoma cells (passages 70-89) were grown in tissue culture flasks $\left(75 \mathrm{~cm}^{2} / 250 \mathrm{~mL}\right.$ ) in $20 \mathrm{~mL}$ of DMEM supplemented with $10 \%$ (v/v) of fetal calf serum with $1 \%$ penicillin/streptomycin. The osmolarity of the medium was 330-340 mOsM. Cells were grown at $37^{\circ} \mathrm{C}$ in a humidified atmosphere containing $10 \% \mathrm{CO}_{2}$. The medium was aspirated and cells detached from the flask with a trypsin-versene mixture (Cambrex Bio Science, Walkersville, MD). Cells were then resuspended in DMEM/10\% fetal calf serum with penicillin/streptomycin and subcultured into $35-\mathrm{mm}$, six-well culture plates at a density of 250-300,000 cells/well for 4 to 5 days. Cells that had reached 70-90\% confluence with a protein content of $\sim 0.25 \mathrm{mg}$ protein per well were routinely used.

\section{Measurement of taurine influx}

SH-SY5Y neuroblastoma cells were washed twice with $2 \mathrm{~mL}$ of isotonic buffer $(142 \mathrm{mM}$ $\mathrm{NaCl}, 5.6 \mathrm{mM} \mathrm{KCl}, 2.2 \mathrm{mM} \mathrm{CaCl}_{2}, 3.6 \mathrm{mM} \mathrm{NaHCO}_{3}, 1 \mathrm{mM} \mathrm{MgCl}_{2}, 30 \mathrm{mM}$ HEPES, pH 7.4 , and $1 \mathrm{mg} / \mathrm{mL}$ D-glucose, $\sim 340 \mathrm{mOsM})$. Unless specified otherwise, cells $(\sim 0.25 \mathrm{mg}$ protein) were then incubated for $10 \mathrm{~min}$ at $37^{\circ} \mathrm{C}$ in buffer (380-230 mOsM) that contained 5 $\mu \mathrm{M}\left[{ }^{3} \mathrm{H}\right]$ taurine $(0.1-0.2 \mu \mathrm{Ci} / \mathrm{mL})$ in the presence or absence of agonist. A potential complication of the measurement of both basal- and Oxo-M-mediated taurine uptake under hypoosmotic conditions is that a concurrent release of endogenous taurine from the cells might lower the specific activity of $\left[{ }^{3} \mathrm{H}\right]$ taurine. To minimize the contribution of taurine released from cells during measurements of taurine uptake, a $5 \mathrm{~mL}$ assay volume $(25 \mathrm{nmol}$ of added taurine) was routinely employed. From measurement of taurine contents in SHSY5Y cells (see Results) and assuming a 20-30\% release of taurine during a $10 \mathrm{~min}$ incubation under receptor-stimulated conditions (Heacock et al. 2006; Cheema et al. 2007), it can be calculated that the maximal contribution from release of endogenous taurine in each well is $\sim 3-4 \mathrm{nmol}$ (a potential 11-14\% reduction in specific activity). However this value is likely to be an over-estimate since it assumes that taurine is released instantaneously from cells, whereas receptor-mediated efflux of taurine has been demonstrated to occur in a time-dependent manner during the 10 min incubation (Heacock et al. 2006). Two additional series of experiments were conducted to further assess the possibility that the release of endogenous taurine might complicate interpretation of the results. In the first, basal- and Oxo-M-mediated changes in taurine uptake were monitored in the presence of an increased 
assay volume $(10 \mathrm{~mL})$, conditions under which a contribution from endogenous taurine would be reduced. However, the rates of taurine uptake under both basal and agoniststimulated conditions were indistinguishable when monitored in 5 or $10 \mathrm{~mL}$ volumes and the addition of Oxo-M resulted in $52 \pm 2$ and $49 \pm 2 \%$ inhibition of uptake, respectively $(\mathrm{p}<0.01 \mathrm{vs}$ basal, $\mathrm{n}=4)$. In a second series of experiments, we used to advantage the observations that (i) mAChR-mediated inhibition of taurine influx does not readily desensitize (see Fig. 1A) and (ii) the mAChR-sensitive pool of taurine is readily releasable. Thus cells were first preincubated for $5 \mathrm{~min}$ at $37^{\circ} \mathrm{C}$ in the presence of $100 \mu \mathrm{M}$ Oxo-M in hypoosmotic buffer (230 mOsM), conditions under which $~ 75 \%$ of the $\mathrm{mAChR}$-sensitive pool of taurine is released (Heacock et al. 2006). Following the preincubation period, the medium was aspirated and cells washed with $2 \mathrm{~mL}$ of hypotonic buffer to remove residual taurine. Cells were then incubated for an additional $20 \mathrm{~min}$ in hypotonic buffer at $37^{\circ} \mathrm{C}$ in the presence or absence of Oxo-M and taurine uptake monitored following the addition of $\left[{ }^{3} \mathrm{H}\right]$ taurine. Under these conditions, the addition of Oxo-M also resulted in a marked inhibition of taurine uptake ( $43 \pm 4 \%, \mathrm{p}<0.01 \mathrm{vs}$ basal, $\mathrm{n}=5$ ). In cells prelabeled to equilibrium with $\left[{ }^{3} \mathrm{H}\right]$ taurine, the rate of $\left[{ }^{3} \mathrm{H}\right]$ taurine efflux monitored during the $5 \mathrm{~min}$ preincubation period under Oxo-M-stimulated conditions exceeded that observed during the subsequent $20 \mathrm{~min}$ incubation period by $\sim 10$-fold ( $3.93 \pm 0.30$ vs. $0.37 \pm 0.007$ percent of initial radioactivity released/min, respectively, $n=4, p<0.01$ ). Both series of experiments indicate that the release of endogenous taurine does not have a significant impact on the measurement of rates of $\left[{ }^{3} \mathrm{H}\right]$ taurine uptake.

Throughout the present study a $5 \mathrm{~mL}$ assay volume was routinely employed except when taurine concentrations of $<5 \mu \mathrm{M}$ were utilized (as for the substrate-dependence studies shown in Fig. 4). In those experiments, the assay volume was increased to $10 \mathrm{~mL}$ to reduce the possibility of a significant dilution of the specific activity when the lower concentrations of taurine were employed. To terminate the reactions involving measurement of taurine uptake, the extracellular medium was aspirated, cells rapidly washed with $2 \mathrm{~mL}$ of isotonic buffer A and lysed with $2 \mathrm{~mL}$ of $0.1 \mathrm{M} \mathrm{NaOH}$. Aliquots of lysate $(1 \mathrm{~mL})$ were removed and radioactivity determined after the addition of $6.5 \mathrm{~mL}$ of Universol scintillation fluid. In all measurements, radioactivity associated with the cells at the zero time point was subtracted from the observed values. Except when indicated otherwise, the osmolarity of buffers was routinely adjusted under conditions of a constant $\mathrm{NaCl}$ concentration $(95 \mathrm{mM} \mathrm{NaCl})$ by the addition of sucrose. In some experiments, buffers were rendered either hypertonic or hypotonic by an increase or decrease in $\mathrm{NaCl}$ concentration, respectively. Osmolarities of buffers were monitored by means of an Osmette Precision osmometer (PS Precision Systems, Sudbury, MA). Protein contents of cell lysates were determined using a bicinchoninic acid protein assay reagent kit (Thermo Scientific; Rockford, IL). From the measurement of $\left[{ }^{3} \mathrm{H}\right]$ taurine uptake, rates of taurine influx were calculated as $\mathrm{nmol} / \mathrm{mg}$ protein/min. Throughout the study, "basal" uptake of taurine is defined as that which occurs at a specified osmolarity in the absence of an agonist.

\section{Measurement of taurine efflux}

Taurine efflux from SH-SY5Y cells was monitored essentially as previously described (Heacock et al. 2004, 2006) . In brief, cells were prelabeled to isotopic equilibrium with 0.25 $\mu \mathrm{Ci} / \mathrm{mL}$ of $\left[{ }^{3} \mathrm{H}\right]$ taurine at $37^{\circ} \mathrm{C}$ for $24 \mathrm{~h}$. After prelabeling, the cells were washed twice with $2 \mathrm{~mL}$ of isotonic buffer $\mathrm{A}(\sim 340 \mathrm{mOsM})$ and then incubated at $37^{\circ} \mathrm{C}$ in $2 \mathrm{~mL}$ of buffer $\mathrm{A}$ (370-230 mOsM) in the absence or presence of agonist. The osmolarity of buffer A was adjusted under conditions of a constant $\mathrm{NaCl}$ concentration $(95 \mathrm{mM} \mathrm{NaCl})$ by the addition of sucrose. After $10 \mathrm{~min}$ of incubation, aliquots $(1 \mathrm{~mL})$ of the extracellular medium were removed and radioactivity determined after the addition of $6.5 \mathrm{~mL}$ of Universol scintillation fluid. The reactions were terminated by rapid aspiration of the remaining medium, and cells 
were lysed by the addition of $2 \mathrm{~mL}$ of $6 \%$ trichloroacetic acid. Taurine efflux was calculated as a fractional release, i.e., the radioactivity released into the extracellular medium as a percentage of the total radioactivity present initially in the cells. The latter was calculated as the sum of radioactivity recovered in the extracellular buffer and that remaining in the lysate at the end of the assay. 'Basal' efflux of taurine is defined as that which occurs at a specified osmolarity in the absence of an agonist.

\section{Determination of taurine mass}

Taurine concentrations were determined following $o$-phthaldialdehyde (OPA) derivatization, essentially as previously described (Canevari et al. 1992; Alvarez et al. 2006). SH-SY5Y cells were washed with $2 \times 2 \mathrm{~mL}$ of isotonic buffer A and then lysed in $2 \mathrm{~mL}$ of ice cold $6 \%$ TCA. Cell extracts were neutralized ( $\mathrm{pH} 7-8$ ) by addition of $\mathrm{K}_{2} \mathrm{CO}_{3}$ and diluted 1:1 with sodium borate buffer $(0.2 \mathrm{M}, \mathrm{pH}$ 9.6). A $50 \mu \mathrm{l}$ aliquot of each sample was removed and derivatized with $25 \mu 1$ of OPA solution (15 mM OPA, $30 \mathrm{mM}$ 2-mercaptoethanol, and 10\% methanol in $0.2 \mathrm{M}$ sodium borate buffer, $\mathrm{pH}$ 9.6) in an autosampler (Agilent 1100 series) for $1 \mathrm{~min}$ at $10^{\circ} \mathrm{C}$. A $10 \mu \mathrm{l}$ aliquot of the derivatized sample was then injected into the HPLC column (ZORBAX Eclipse XDB-C18 $(5 \mu \mathrm{m})$ analytical column $4.6 \times 150 \mathrm{~mm})$ and eluted at a flow rate of $1 \mathrm{ml} / \mathrm{min}$ with buffers $\mathrm{A}(80 \% 0.1 \mathrm{M}$ sodium acetate and $20 \%$ methanol, $\mathrm{pH}$ 4.75) and $\mathrm{B}(20 \% 0.1 \mathrm{M}$ sodium acetate and $80 \%$ methanol, $\mathrm{pH} 4.75)$. The following increasing gradient of buffer B was used for elution: $0-10 \mathrm{~min}, 30$ to $60 \%$; 10-15 min, 60 to $100 \%$; $15-20 \mathrm{~min}, 100 \%$; 20-22 min, 100 to $30 \%$; 22-30 min, 30\%, with a corresponding decrease in the percentage of buffer A. The detector was set at $340 \mathrm{~nm}$ excitation and 450 $\mathrm{nm}$ emission wavelengths, taurine concentrations were determined using calibration coefficients obtained with standard taurine solutions. Protein contents of cell lysates were determined using a bicinchoninic acid protein assay reagent kit (Thermo Scientific; Rockford, IL) and values for intracellular taurine content in SH-SY5Y cells were reported as $\mathrm{nmol} / \mathrm{mg}$ protein. To determine the taurine content in the cell culture medium, DMEM supplemented with $10 \%$ fetal calf serum was mixed 1:1 with 10\% TCA and the resulting protein precipitate was removed by centrifugation. The supernatant was neutralized to $\mathrm{pH} 7-$ 8 by addition of $\mathrm{K}_{2} \mathrm{CO}_{3}$ and diluted 1:4 with $0.2 \mathrm{M}$ sodium borate buffer ( $\mathrm{pH}$ 9.6) prior to OPA-derivatization and subsequent HPLC analysis as outline above.

\section{Data Analysis}

All experiments shown were performed in duplicate or triplicate and repeated at least three times. Values quoted are given as means \pm SEM for the number (n) of independent experiments indicated. A two-tailed Student's t test (paired or unpaired) was used to evaluate differences between two experimental groups (level of significance, $p<0.05$ ). Ordinary or repeated measures analysis of variance (ANOVA) followed by Dunnett's multiple comparisons test was used for statistical significance of differences between multiple groups. $\mathrm{EC}_{50}$ values were obtained using Prism 5.0 (GraphPad Software Inc., San Diego, CA). Kinetic analysis of taurine uptake data was performed as previously reported (Schousboe et al. 1976; Olson and Martinho 2006a). Data were fit to the sum of carriermediated transport and diffusional components using a non-linear least squares approximation according to the following equation (Equation 1):

$$
V=\frac{V_{\max } \bullet[\mathrm{S}]}{K_{\mathrm{m}}+[\mathrm{S}]}+k_{\mathrm{diff}} \bullet[\mathrm{S}]
$$

Kinetic values quoted are the best-fit values \pm standard error as derived using Prism 5.0 (Graph Pad Software Inc., San Diego, CA). In this equation $V$ is the observed rate of taurine uptake (nmol/mg protein/min), $V_{\max }$ is the maximum rate of taurine uptake, $K_{\mathrm{m}}$ is the 
taurine affinity binding constant $(\mu \mathrm{M})$ for the saturable component of taurine uptake, $k_{\text {diff }}$ is the rate constant for the non-saturable, diffusion-mediated, taurine influx ( $\mathrm{ml} / \mathrm{mg}$ protein/ $\min$ ) and $\mathrm{S}$ is the concentration of extracellular taurine $(\mu \mathrm{M})$. From this equation the relative contributions of both the saturable, carrier-mediated, component and the non-saturable, diffusional, component could be determined.

\section{Results}

\section{Taurine uptake into SH-SY5Y neuroblastoma cells is regulated by both hypoosmolarity and receptor activation}

When SH-SY5Y cells were incubated in isotonic buffer (340 mOsM; defined by the osmolarity of the DMEM/fetal calf serum medium in which the cells were grown) that contained $5 \mu \mathrm{M}$ taurine, the uptake of taurine proceeded linearly for at least $1 \mathrm{~h}$ at a rate of $0.067 \mathrm{nmol} / \mathrm{mg}$ protein/min (Fig. 1A). Taurine uptake was strongly dependent on the concentration of extracellular $\mathrm{NaCl}$ (Fig. 1B) and was inhibited $>95 \%$ when incubations were conducted at $4^{\circ} \mathrm{C}$ (data not shown). Inclusion of $1 \mathrm{mM}$ concentrations of GES, $\beta$ alanine and hypotaurine essentially completely blocked taurine uptake (Fig. 1C). To the best of our knowledge, the taurine content of SH-SY5Y cells has not previously been reported. HPLC analysis indicated that the taurine content was $57 \pm 10 \mathrm{nmol} / \mathrm{mg}$ protein $(\mathrm{n}=7)$. Given that the intracellular water space in SH-SY5Y cells is $8.5 \mu 1 / \mathrm{mg}$ protein (Foster et al. 2008), an intracellular taurine concentration of $\sim 6-7 \mathrm{mM}$ can be calculated. The concentration of taurine in the growth medium was $12.9 \pm 1.1 \mu \mathrm{M}(\mathrm{n}=3)$ and thus taurine is concentrated over 500-fold by SH-SY5Y cells.

Exposure of the cells to hypotonic buffer ( $230 \mathrm{mOsM} ; 30 \%$ reduction in osmolarity, a condition previously determined to be optimal for the release of organic osmolytes) resulted in a significant reduction in the rate of taurine influx $(0.043 \mathrm{nmol} / \mathrm{mg}$ protein $/ \mathrm{min} ; \mathrm{p}<0.01 \mathrm{vs}$ isotonic by ordinary ANOVA). Inclusion of the muscarinic cholinergic agonist, Oxo-M (100 $\mu \mathrm{M})$, resulted in a further attenuation $(\sim 50 \%)$ of taurine influx (rate $=0.020 \mathrm{nmol} / \mathrm{mg}$ protein/min; $\mathrm{p}<0.01$ vs. hypotonic alone by ordinary ANOVA, Fig. 1A). The inhibition of taurine uptake observed under conditions of hypotonicity and receptor activation could be detected within $2 \mathrm{~min}$ of incubation (the earliest time point examined) and persisted for as long as $1 \mathrm{~h}$, a time-frame in which cell volume correction may already be complete.

Although taurine influx was linear with time for extended time periods, uptake was routinely monitored after $10 \mathrm{~min}$ of incubation to match conditions previously utilized for measurement of osmolyte efflux. The addition of Oxo-M reduced the rate of taurine influx under conditions of hypotonicity in a dose-dependent manner with an $\mathrm{EC}_{50}$ of $0.7 \mu \mathrm{M}$ and a Hill coefficient close to unity (Fig. 2). Inclusion of $10 \mu \mathrm{M}$ atropine, a mAChR antagonist, abolished the ability of Oxo-M to inhibit taurine influx (data not shown).

\section{Activation of multiple GPCRs can attenuate taurine influx}

In addition to the mAChR, activation of several other GPCRs has been demonstrated to increase the volume-dependent efflux of both organic and inorganic osmolytes from SHSY5Y cells, including the protease-activated receptor (PAR) and lysophospholipid receptors (Cheema et al. 2005; Heacock et al. 2006). To determine whether activation of these receptors also attenuates the uptake of taurine, SH-SY5Y cells were incubated in either isotonic (340 mOsM) or hypotonic (230 mOsM) buffer in the presence or absence of 100 $\mu \mathrm{M}$ Oxo-M, $1.25 \mathrm{nM}$ thrombin (a PAR agonist), or $5 \mu \mathrm{M}$ sphingosine 1-phosphate (S1P, an agonist at specific lysophospholipid receptors). Although the addition of each of the three agonists resulted in small but significant decreases in the rate of taurine uptake under isotonic conditions, inhibition of taurine uptake following receptor activation was more pronounced under hypoosmotic conditions (Fig. 3). Thus the net ability of Oxo-M to 
attenuate the rate of taurine uptake was significantly enhanced under hypotonic conditions $(0.0113 \pm 0.001 \mathrm{vs} 0.0141 \pm 0.007 \mathrm{nmol} / \mathrm{mg}$ protein $/ \mathrm{min}$ under conditions of isotonicity and hypotonicity, respectively, $\mathrm{n}=15, \mathrm{p}<0.01)$. Similarly, the addition of thrombin resulted in a greater net reduction in taurine uptake under conditions of hypotonicity $(0.007 \pm 0.002$ vs $0.0132 \pm 0.002 \mathrm{nmol} / \mathrm{mg}$ protein $/ \mathrm{min}, \mathrm{n}=5, \mathrm{p}<0.05$ ). The comparable values for S1Pmediated reductions in taurine uptake were $0.004 \pm 0.002 \mathrm{vs} 0.011 \pm 0.002 \mathrm{nmol} / \mathrm{mg}$ protein/min under isotonic and hypotonic conditions, respectively $(\mathrm{n}=9, \mathrm{p}<0.01)$. These results suggest that inhibition of taurine influx is a shared characteristic of GPCRs that have previously been demonstrated to facilitate the volume-dependent efflux of taurine.

\section{Substrate concentration-dependence of taurine uptake in the absence or presence of mAChR activation}

Previous studies have demonstrated that, under conditions of hypoosmolarity, taurine uptake into neural cells occurs via both saturable (carrier-mediated) and non-saturable (diffusional) components (Schousboe et al. 1976; Olson and Martinho 2006a). To determine the contribution of these two processes to taurine uptake in SH-SY5Y cells, the rate of influx was monitored in the presence of a series of physiologically relevant taurine concentrations, in the absence or presence of $100 \mu \mathrm{M}$ Oxo-M. Under isotonic conditions, a rectangular hyperbolic dose-response plot was obtained with values of $0.087 \pm 0.005 \mathrm{nmol} / \mathrm{mg}$ protein/ min and $2.5 \pm 0.5 \mu \mathrm{M}$ for the $V_{\max }$ and $K_{\mathrm{m}}$, respectively (Fig. 4A). The diffusional constant $\left(k_{\text {diff }}\right)$ was $3.1 \pm 6.6 \times 10^{-5} \mathrm{ml} / \mathrm{mg}$ protein $/ \mathrm{min}$. When the cells were incubated in hypotonic buffer, the $V_{\max }$ was significantly decreased from that observed under isotonic conditions $\left(0.041 \pm 0.002 \mathrm{nmol} / \mathrm{mg}\right.$ protein/min; $\mathrm{p}<0.001$ by ordinary ANOVA) whereas the $K_{\mathrm{m}}$ value for taurine uptake was unaltered $(2.8 \pm 0.5 \mu \mathrm{M}$; Fig. 4B). The dose-response curve for taurine uptake in the presence of Oxo-M differed significantly from that obtained under conditions of hypoosmolarity alone. From the data in Fig. 4B, it appeared that inclusion of Oxo-M resulted in an inhibition of taurine uptake at low concentrations $(1-20 \mu \mathrm{M})$, but that the agonist had little or no effect at higher concentrations of the osmolyte $(>50 \mu \mathrm{M})$. However, when the data in Fig. 4B were fitted to Equation 1 to subtract the diffusional component of taurine influx, rectangular hyperbolic dose-response plots were obtained for Oxo-M-treated cells (Fig. 4C). In the presence of Oxo-M, the $V_{\max }$ for saturable taurine uptake $(0.026 \pm 0.003 \mathrm{nmol} / \mathrm{mg}$ protein $/ \mathrm{min})$ was significantly reduced $(\sim 40 \%$ : $\mathrm{p}<0.01$, by ordinary ANOVA) from control hypotonic incubations, whereas the $K_{m}$ value for taurine transport did not differ significantly in the presence of Oxo-M $(4.7 \pm 1.7 \mu \mathrm{M})$. However, the diffusional component of taurine uptake was significantly increased ( 6-fold) by Oxo-M $\left(2.13 \pm 0.40 \times 10^{-4} \mathrm{ml} / \mathrm{mg}\right.$ protein $/ \mathrm{min}$ vs. $3.55 \pm 2.8 \times 10^{-5} \mathrm{ml} / \mathrm{mg}$ protein $/ \mathrm{min}$ in hypotonic buffer alone; $\mathrm{p}<0.02$, by ordinary ANOVA). Based on these values, it can be calculated that, even in the presence of Oxo-M, $>85 \%$ of taurine uptake occurs via the saturable component of transport when monitored in the presence of the standard assay concentration of $5 \mu \mathrm{M}$. The diffusional component of taurine influx monitored in the presence of Oxo-M was essentially abolished when DCPIB was included in the assay ( $k_{\text {diff }}=1.57 \times 10^{-16} \mathrm{ml} / \mathrm{mg}$ protein $/ \mathrm{min}$ ). Thus, the non-specific component of taurine uptake appears to be mediated primarily via VSOAC.

\section{Osmolarity dependence of basal- and Oxo-M-attenuated taurine uptake}

Activation of mAChRs has previously been demonstrated to facilitate taurine efflux in an osmosensitive fashion by reducing the threshold osmolarity at which osmolyte efflux occurs (Heacock et al. 2004). To assess the effect of osmolarity on taurine uptake, SH-SY5Y cells were incubated in isotonic $(340 \mathrm{mOsM})$, mildy hypertonic $(380 \mathrm{mOsM})$, or hypotonic (290-230 mOsM) buffers under basal- or Oxo-M-stimulated conditions. Two experimental paradigms were employed to evaluate the dependence of taurine uptake on osmolarity. In the first, osmolarities of buffers were adjusted under conditions of a constant $\mathrm{NaCl}$ 
concentration ( $95 \mathrm{mM}$ ) by the addition of sucrose. Because taurine transport is a $\mathrm{NaCl}-$ dependent process, this paradigm allows for assessment of the effect of osmolarity per se on the rate of taurine influx. Under these conditions, basal uptake was not significantly attenuated until the osmolarity had been reduced by $>24 \%$ (Fig. 5A). Although the addition of Oxo-M induced a significant decrease in the rate of taurine influx under both isotonic and mildly hypertonic conditions (28-38\%), the ability of mAChR activation to attenuate taurine influx was significantly increased under conditions of hypotonicity. Inclusion of Oxo-M resulted in a significant reduction in taurine uptake relative to that observed under isotonic conditions when the osmolarity was reduced by $\sim 15 \%$ (340 to $290 \mathrm{mOsM}$; Fig. 5A). In the second experimental paradigm, buffers were rendered either hypertonic or hypotonic by increases or decreases, respectively, in $\mathrm{NaCl}$ concentration (because $\mathrm{Na}^{+}$and $\mathrm{Cl}^{-}$are the primary osmolytes found in plasma and reductions in plasma osmolarity observed under pathological conditions, such as hyponatremia, principally reflect changes in the concentrations of these ions). Under these conditions, the basal uptake of taurine was reduced below that observed under isotonic conditions when the osmolarity was lowered to $260 \mathrm{mOsM}$, whereas in the presence of Oxo-M, taurine uptake was significantly attenuated following a reduction in osmolarity of 15\% (290 mOsM: Fig. 5B). Under both experimental paradigms, the ability of Oxo-M to inhibit taurine uptake was most pronounced at 230 mOsM (55-64\% relative to basal uptake).

\section{Oxo-M-mediated inhibition of taurine influx: effect of $\mathrm{Ca}^{2+}$ depletion and inhibitors of protein kinase $\mathbf{C}(\mathrm{PKC})$ activity}

The ability of mAChRs to facilitate osmosensitive taurine efflux is dependent upon both the availability of $\mathrm{Ca}^{2+}$ and PKC activity. For example, under conditions of a limited $\mathrm{Ca}^{2+}$ availability, mAChR-stimulated taurine efflux is inhibited by $60-81 \%$, whereas inhibition of PKC with chelerythrine resulted in a $73 \%$ reduction in efflux (Cheema et al. 2007). mAChR-mediated inhibition of taurine influx was also dependent upon $\mathrm{Ca}^{2+}$ availability. Thus although removal of extracellular $\mathrm{Ca}^{2+}$ had no effect on the basal influx of taurine under hypotonic (230 mOsM) conditions, it significantly attenuated $(\sim 50 \%)$ the ability of Oxo-M to inhibit taurine influx. Removal of intracellular $\mathrm{Ca}^{2+}$ stores with $1 \mu \mathrm{M}$ thapsigargin in the absence of extracellular $\mathrm{Ca}^{2+}$ elicited a significant increase $(\sim 30 \%)$ in the basal uptake of taurine, but did not further reduce the ability of Oxo-M to inhibit taurine influx (Fig. 6). To evaluate a role for PKC in taurine uptake, cells were pre-incubated for 10 min with $2.5 \mu \mathrm{M}$ bisindolylmaleimide 1 (BIM), a broad spectrum inhibitor of PKC. BIM had no discernable effect on TauT activity under either isotonic or hypotonic conditions in the absence or presence of Oxo-M (Fig. 7A). In contrast, preincubation of the cells with BIM resulted in a 49\% reduction in Oxo-M-stimulated taurine efflux (Fig 7B). To further evaluate the possible involvement of PKC in regulation of TauT activity, cells were preincubated with $2.5 \mu \mathrm{M}$ concentrations of two additional PKC inhibitors, namely Gö 6983 and Ro-31-8220. Although neither of these inhibitors significantly attenuated either basal- or Oxo-M-stimulated taurine influx, both significantly reduced Oxo-M-stimulated (30-53\%) taurine efflux (Fig. 7C,D). Acute activation of PKC, mediated by the acute addition of 100 nM PMA, did not significantly alter taurine uptake $(0.045 \pm 0.002 \mathrm{nmol} / \mathrm{mg}$. protein $/ \mathrm{min} v \mathrm{v}$. $0.050 \pm 0.004 \mathrm{nmol} / \mathrm{mg}$. protein $/ \mathrm{min}, \mathrm{n}=3$ ).

\section{DCPIB, an inhibitor of VSOAC, attenuates both basal- and OxO-M-mediated reductions in taurine uptake}

Although several pharmacological agents have been found to block the swelling-activated efflux of $\mathrm{Cl}^{-}$and organic osmolytes from both neural and non-neural cells, the most selective inhibitor identified to date is DCPIB, a derivative of ethacrynic acid (Decher et al. 2001; Best et al., 2004). To determine whether volume-dependent osmolyte efflux and uptake are coupled or independent events, the ability of DCPIB to prevent the inhibition of 
taurine uptake observed under conditions of hypotonicity and following mAChR activation was evaluated. As previously reported (Heacock et al. 2006; Cheema et al. 2007), preincubation of SH-SY5Y cells with $10 \mu \mathrm{M}$ DCPIB completely prevented increases in taurine efflux observed under conditions of hypotonicity alone or following $\mathrm{mAChR}$ activation (Fig. 8A). Under hypoosmotic conditions, the effects of DCPIB on basal- and Oxo-M-stimulated taurine efflux were dose-dependent with a $3 \mu \mathrm{M}$ concentration of the inhibitor attenuating $\sim 50 \%$ of the responses (Fig. 8A). The inhibition of TauT activity observed under basal conditions was also dose-dependently reversed by increases in DCPIB concentration (Fig. 8B). In contrast, reversal of Oxo-M-mediated inhibition of TauT activity (i.e. the net reduction of uptake due to agonist addition) was not observed until DCPIB concentrations had been increased to $>6 \mu \mathrm{M}$. Thus, under mAChR-regulated conditions, taurine influx is not attenuated by DCPIB until efflux is substantially inhibited. DCPIB had no effect on basal taurine uptake under isotonic conditions $(0.040 \pm 0.002$ vs $0.044 \pm 0.001 \mathrm{nmol} / \mathrm{mg}$ protein/min in the absence or presence of $10 \mu \mathrm{M}$ DCPIB, respectively, $\mathrm{n}=5$ ), a result that indicates the absence of any direct effect of DCPIB on the taurine transporter itself. We then extended the studies with DCPIB to include measurement of $\mathrm{K}^{+}$fluxes (as monitored by ${ }^{86} \mathrm{Rb}^{+}$) since we have recently reported that hypotonicity and $\mathrm{mAChR}$ activation can regulate both the influx and efflux of the cation in these cells (Foster et al. 2008). Although a reduction in osmolarity of $\sim 30 \%$ resulted in little or no change in either $\mathrm{K}^{+}$efflux or influx, inclusion of Oxo-M resulted in significant increases in both parameters. Inclusion of DCPIB inhibited the mAChR-mediated increases in both ${ }^{86} \mathrm{Rb}^{+}$efflux and influx by $>80 \%$ but had little or no effect on $\mathrm{K}^{+}$fluxes monitored under isotonic conditions (Fig. 9A,B). These results suggest that, in SH-SY5Y cells, volume-dependent osmolyte efflux mediated via VSOAC may result in a coordinated regulation of the uptake of both organic and inorganic osmolytes.

\section{Discussion}

Although the release of the quantitatively major osmolyte, taurine, can be enhanced from a variety of neural preparations in response to both hypoosmolarity and the activation of specific GPCRs, the possibility that the re-uptake of taurine is subject to similar regulation has received little attention. This issue is of potential physiological significance since the net loss of an osmolyte from a tissue will reflect not only changes in its efflux but also in its reuptake. The major finding to emanate from the present study is that, in SH-SY5Y neuroblastoma cells, the uptake of taurine is inhibited by both a reduction in osmolarity and in response to activation of those GPCRs (mAChR, S1P and PAR) that have previously been demonstrated to facilitate volume-dependent osmolyte efflux. Thus hypoosmolarity and activation of GPCRs serve not only to enhance the efflux of taurine from SH-SY5Y cells but also to limit its re-uptake, the net effect being a more pronounced loss of the osmolyte.

Under isotonic conditions, taurine uptake into SH-SY5Y cells is mediated via a highaffinity, $\mathrm{Na}^{+}$-dependent, saturable transport system with pharmacological characteristics shared by the two cloned taurine transporters TauT-1 and TauT-2 (Liu et al. 1992; Smith et al. 1992; Pow et al. 2002). The $K_{\mathrm{m}}$ for taurine uptake in SH-SY5Y cells $(2.5 \mu \mathrm{M})$, is similar to that reported for TauT-2 (Liu et al., 1992; Pow et al., 2002), an isoform of TauT that is widely distributed across different brain regions. In contrast, a lower affinity for uptake has been reported for the cloned TauT-1 transporter or for taurine uptake into astrocyte preparations $\left(K_{\mathrm{m}}=20-45 \mu \mathrm{M}\right.$; Smith et al. 1992; Holopainen et al. 1987; Sanchez-Olea et al. 1991). The calculated intracellular taurine concentration in SH-SY5Y cells $(6-7 \mathrm{mM})$ is similar to that reported for whole brain (McIlwain and Bachelard, 1971), but lower than that observed for astrocytes (Beetsch and Olson 1991; Olson 1999). 
Exposure of SH-SY5Y cells to hypotonicity resulted in a sustained inhibition of taurine uptake, that was attributable to a reduction in the $V_{\max }$ for transport whereas the $K_{\mathrm{m}}$ value was unaffected. This reduction in taurine uptake, which could be observed under conditions in which the $\mathrm{Na}^{+}$concentration of the buffer was either lowered or maintained constant, was evident when the osmolarity was reduced by $>20 \%$. Under the hypotonic conditions routinely employed ( $\sim 30 \%$ reduction in osmolarity), $>99 \%$ of taurine uptake monitored at a $5 \mu \mathrm{M}$ concentration was mediated via the high-affinity transport system. The diffusional component of taurine uptake in SH-SY5Y cells was minimal under isotonic conditions and little or no increase in this parameter occurred under hypoosmotic conditions (Fig. 4). Our observation that hypotonicity reduces the $V_{\max }$ for taurine uptake in SH-SY5Y cells without an effect on the $K_{\mathrm{m}}$ is in agreement with the results of a recent study of primary hippocampal neurons in which taurine uptake was also attenuated (by 48\%) in response to a $30 \%$ reduction in osmolarity (Olson and Martinho 2006a). Although the mechanism underlying the reduction of TauT activity under basal hypoosmotic conditions remains to be determined, possibilities to be considered include the involvement of a tyrosine kinase (Olson and Martinho, 2006b) and internalization of the transporter (Han et al 2006).

Activation of GPCRs also resulted in an attenuation of taurine uptake in SH-SY5Y cells. Following activation of the mAChR, PAR-1 or S1P receptors, a small attenuation of taurine uptake was observed under isotonic conditions but the extent of receptor-mediated inhibition was enhanced when the cells were incubated in a hypoosmotic buffer (Fig. 3). To the best of our knowledge, this is the first report of receptor-mediated, volume-dependent, regulation of the uptake of an organic osmolyte. Previously, we have demonstrated that the influx of $\mathrm{K}^{+}$is also under receptor control in these cells (Foster et al., 2008). Attenuation of taurine uptake in SH-SY5Y cells under hypoosmotic conditions was examined in more detail for the $\mathrm{mAChR}$. The addition of Oxo-M resulted in a concentration-dependent inhibition of taurine uptake with an $\mathrm{EC}_{50}$ of $0.7 \mu \mathrm{M}$, whereas the comparable value for Oxo-M-stimulated taurine efflux is $2.3 \mu \mathrm{M}$ (Heacock et al. 2004). Receptor-mediated inhibition of taurine uptake under hypoosmotic conditions was sustained for at least $1 \mathrm{~h}$ of incubation and could be observed under conditions of relatively limited reductions in osmolarity (15\%: Fig. 5). $\mathrm{mAChR}$-mediated reductions in taurine uptake under hypoosmotic conditions were primarily due to a reduction in $V_{\max }$, with little or no effect on the $K_{\mathrm{m}}$ (Fig. 4C).

A common characteristic of those GPCRs that have been previously demonstrated to facilitate the efflux of osmolytes in SH-SY5Y cells is a dependence on both $\mathrm{Ca}^{2+}$ availability and PKC activity. Similarly, the magnitude of the $\mathrm{mAChR}$-mediated reduction in taurine influx was also partially reversed (50-60\%) following removal of extracellular $\mathrm{Ca}^{2+}$, although the dependence on $\mathrm{Ca}^{2+}$ was less marked than that previously observed for stimulated taurine efflux (Cheema et al 2007). However, mAChR-mediated changes in taurine efflux and influx appeared to differ significantly in their dependence upon PKC activity. Thus, whereas inclusion of BIM, Gö 6983 or Ro-31-8220, three broad-spectrum inhibitors of PKC, had no effect on either basal-or receptor-mediated changes in taurine influx, all three inhibitors significantly attenuated mAChR-stimulated taurine efflux ( $\sim 30$ 53\%: Fig. 7). Two interpretations of these results are possible. The first is that $\mathrm{mAChR}$ activation independently regulates taurine influx and efflux and that these processes are differentially sensitive to PKC inhibition. Alternatively, mAChR-mediated changes in VSOAC activity may be a prerequisite for the regulation of taurine influx and a relatively small increase in osmolyte efflux is sufficient for maximal attenuation of TauT activity. This possibility is further discussed below in the context of the results obtained with DCPIB.

Changes in the magnitude of taurine influx and efflux that occur under basal- and mAChRstimulated conditions are not strictly proportional. For example, TauT activity is inhibited to a similar extent following either a $30 \%$ reduction in osmolarity or activation of mAChRs 
under hypoosmotic conditions. In contrast, much larger increases in taurine efflux are elicited in response to the addition of Oxo-M than to a reduction in osmolarity (see Fig. 8). However, evidence to suggest that basal- and receptor-mediated changes in the influx and efflux of taurine are linked, rather than independent, events was obtained from experiments with DCPIB, a selective inhibitor of VSOAC. Inclusion of a maximally effective concentration of DCPIB $(10 \mu \mathrm{M})$ resulted not only in a $>70-90 \%$ inhibition of basal-and mAChR-mediated increases in taurine efflux, as would be predicted, but the inhibitor also prevented the attenuation of taurine influx under these conditions. Since DCPIB has no direct effect on taurine transporter activity, the most parsimonious interpretation of these results is that the activation of VSOAC and regulation of TauT activity are mechanistically inter-related events. Reversal of changes in basal taurine efflux and influx by DCPIB demonstrated a similar dose-dependence. In contrast, mAChR-mediated increases in taurine efflux were more sensitive to lower concentrations of DCPIB than was the attenuation of taurine influx (Fig. 8). This result, suggests that for maximal attenuation of taurine influx to occur, only relatively limited increases in VSOAC activity are required and that more substantial increases in the rate of efflux do not result in further reductions of taurine influx. This observation may be relevant when considering the lack of PKC regulation of mAChRattenuated taurine influx, since none of the inhibitors employed blocked efflux by $>53 \%$. Further evidence to suggest that VSOAC activity may be linked to osmolyte influx was obtained from experiments in which DCPIB also prevented mAChR-mediated changes in the efflux and influx of $\mathrm{K}^{+}$(Fig. 9). Although a mechanistic link has yet to be established, the results raise the possibility that the activation of VSOAC is a prerequisite for regulatory changes in the release and uptake of both organic and inorganic osmolytes.

Under conditions of chronic hyponatremia the brain selectively retains inorganic osmolytes whereas organic osmolytes are lost (Pasantes-Morales et al. 2002; Massieu et al. 2004). Hypoosmolarity has been demonstrated to result in an increase in a $\mathrm{Ca}^{2+}$-dependent exocytotic release of neurotransmitters from nerve-ending preparations (Tuz et al. 2004; Tuz and Pasantes-Morales 2005). These neurotransmitters may then regulate the activities of GPCRs, present on neighboring cells, that are linked to volume regulation. Our current and previous studies in which we demonstrate that activation of GPCRs can regulate not only the efflux but also the influx of both organic and inorganic osmolytes may provide, in part at least, an explanation for the differential retention in vivo of organic and inorganic osmolytes observed during hyponatremia. There is an increasing body of evidence to suggest that GPCRs can regulate the efflux of osmolytes from a variety of tissues (Fisher et al. 2008: Franco et al. 2008; Vasquez-Juarez et al. 2008). The observation that GPCRs can also regulate the reuptake of osmolytes further emphasizes the potential importance of this class of receptors in osmoregulation.

\section{Abbreviations Used}

$\begin{array}{ll}\text { ANOVA } & \text { analysis of variance } \\ \text { BIM } & \text { bisindolylmaleimide } \\ \text { DCPIB } & \begin{array}{l}\text { 4-[(2-butyl-6,7-dichloro-2-cyclopentyl-2,3-dihydro-1-oxo-1 } H \text {-inden-5- } \\ \text { yl)oxy]butanoic acid }\end{array} \\ \text { DMEM } & \text { Dulbecco's modified Eagle's medium } \\ \text { GES } & \text { guanidinethyl sulfonate } \\ \text { GPCR } & \text { G-protein-coupled receptor } \\ \text { HEPES } & \mathrm{N}-[2 \text { hydroxyethyl]piperazine-N'-[2-ethanesulfonic acid] }\end{array}$


mAChR muscarinic cholinergic receptor

OPA $o$-phthaldialdehyde

Oxо-M oxotremorine-M

PAR protease-activated receptor

PKC protein kinase C

PMA phorbol 12-myristate 13-acetate

S1P sphingosine 1-phosphate

TauT high-affinity taurine transporter

VSOAC volume-sensitive organic osmolyte and anion channel

\section{Acknowledgments}

We thank Drs. Richard Keep and Richard Neubig for their helpful comments. This work was supported by NIH Grants NS23831 (S.K.F.), GM007767 (D.J.F.) and DK 64959 (R.B.)

\section{References}

Alvarez MP, Jimenez V, Cano P, Rebollar P, Cardinali DP, Esquifino AI. Circadian rhythms of prolactin secretion in neonatal female rabbits after acute separation from their mothers. Gen Comp Endocrinol. 2006; 146:257-264. [PubMed: 16426607]

Beetsch JW, Olson JE. Taurine transport in rat astrocytes adapted to hyperosmotic conditions. Brain Res. 1993; 613:10-15. [PubMed: 8348293]

Best L, Yates AP, Decher N, Steinmeyer K, Nilius B. Inhibition of glucose-induced electrical activity in rat pancreatic beta cells by DCPIB, a selective inhibitor of volume-sensitive anion currents. Eur J Pharmacol. 2004; 489:13-19. [PubMed: 15063150]

Bhardwaj A. Neurological impact of vasopressin dysregulation and hyponatremia. Ann Neurol. 2006; 59:229-236. [PubMed: 16437573]

Canevari L, Vieira R, Aldegunde M, Dagani F. High-performance liquid chromatographic separation with electrochemical detection of amino acids focusing on neurochemical application. Anal Biochem. 1992; 205:137-142. [PubMed: 1443551]

Cheema TA, Ward CE, Fisher SK. Subnanomolar concentrations of thrombin enhance the volumesensitive efflux of taurine from human 1321N1 astrocytoma cells. J Pharmacol Exp Ther. 2005; 315:755-763. [PubMed: 16051696]

Cheema TA, Pettigrew VA, Fisher SK. Receptor regulation of the volume-sensitive efflux of taurine and iodide from human SH-SY5Y neuroblastoma cells: differential requirements for $\mathrm{Ca}(2+)$ and protein kinase C. J Pharmacol Exp Ther. 2007; 320:1068-1077. [PubMed: 17148779]

Decher T, Lang HJ, Nilius B, Bruggemann A, Busch AE, Steinmeyer K. DCPIB is a novel selective blocker of $\mathrm{I}(\mathrm{Cl}$,swell $)$ and prevents swelling-induced shortening of guinea-pig atrial action potential duration. Br J Pharmacol. 2001; 134:1467-1479. [PubMed: 11724753]

Fisher SK, Cheema TA, Foster DJ, Heacock AM. Volume-dependent osmolyte efflux from neural tissues:regulation by G-protein-coupled receptors. J Neurochem. 2008; 106:1998-2014. [PubMed: 18518929]

Foster DJ, Heacock AM, Keep RF, Fisher SK. Activation of muscarinic cholinergic receptors on human SH-SY5Y neuroblastoma cells enhances both the influx and efflux of $\mathrm{K}^{+}$under conditions of hypo-osmolarity. J Pharmacol Exp Ther. 2008; 325:457-465. [PubMed: 18281593]

Franco R, Panayiotidis MI, Ochoa de la Paz LD. Autocrine signaling involved in cell volume regulation: the role of released transmitters and plasma membrane receptors. J Cell Physiol. 2008; 216:14-28. [PubMed: 18300263] 
Haussinger D, Laubenberger J, vom Dahl S, Ernst T, Bayer S, Langer M, Gerok W, Hennig J. Proton magnetic resonance spectroscopy studies on human brain myo-inositol in hypo-osmolarity and hepatic encephalopathy. Gastroenterology. 1994; 107:1475-1480. [PubMed: 7926510]

Han X, Patters AB, Jones DP, Zelikovic I, Chesney RW. The taurine transporter: mechanisms of regulation. Acta Physiol. 2006; 187:61-73.

Heacock AM, Dodd MS, Fisher SK. Regulation of volume-sensitive osmolyte efflux from human SHSY5Y neuroblastoma cells following activation of lysophospholipid receptors. J Pharmacol Exp Ther. 2006; 317:685-693. [PubMed: 16415087]

Heacock AM, Kerley D, Gurda GT, VanTroostenberghe AT, Fisher SK. Potentiation of the osmosensitive release of taurine and D-aspartate from SH-SY5Y neuroblastoma cells after activation of M3 muscarinic cholinergic receptors. J Pharmacol Exp Ther. 2004; 311:1097-1104. [PubMed: 15292461]

Holopainen I, Malminen O, Kontro P. Sodium-dependent high-affinity uptake of taurine in cultured cerebellar granule cells and astrocytes. J Neurosci Res. 1987; 18:479-483. [PubMed: 3437468]

Huxtable RJ. Physiological actions of taurine. Physiol Rev. 1992; 72:101-163. [PubMed: 1731369]

Lambert IH. Regulation of the cellular content of the organic osmolyte taurine in mammalian cells. Neurochemical Research. 2004; 29:27-63. [PubMed: 14992263]

Lehmann A. Effects of microdialysis-perfusion with anisoosmotic media on extracellular amino acids in the rat hippocampus and skeletal muscle. J Neurochem. 1989; 53:525-535. [PubMed: 2501452]

Lien YH, Shapiro JI. Hyponatremia: clinical diagnosis and management. Am J Med. 2007; 120:653658. [PubMed: 17679119]

Lien YH, Shapiro JI, Chan L. Study of brain electrolytes and organic osmolytes during correction of chronic hyponatremia. Implications for the pathogenesis of central pontine myelinolysis. J Clin Invest. 1991; 88:303-309. [PubMed: 2056123]

Liu QR, Lopez-Corcuera B, Nelson H, Mandiyan S, Nelson N. Cloning and expression of a cDNA encoding the transporter of taurine and beta-alanine in mouse brain. Proc Natl Acad Sci U S A. 1992; 89:12145-12149. [PubMed: 1465453]

Massieu L, Montiel T, Robles G, Quesada O. Brain amino acids during hyponatremia in vivo: clinical observations and experimental studies. Neurochem Res. 2004; 29:73-81. [PubMed: 14992265]

McIlwain, H.; Bachelard, H. Biochemistry and the Central Nervous System. Edinburgh and London: Churchill Livingstone; 1971. p. 172

McManus ML, Churchwell KB, Strange K. Regulation of cell volume in health and disease. N Engl J Med. 1995; 333:1260-1266. [PubMed: 7566004]

Miller TJ, Hanson RD, Yancey PH. Developmental changes in organic osmolytes in prenatal and postnatal rat tissues. Comp Biochem Physiol A Mol Integr Physiol. 2000; 125:45-56. [PubMed: 10779730]

Okada Y. Cell volume-sensitive chloride channels: phenotypic properties and molecular identity. Contrib Nephrol. 2006; 152:9-24. [PubMed: 17065805]

Olson JE. Osmolyte contents of cultured astrocytes grown in hypoosmotic medium. Biochim Biophys Acta. 1999; 1453:175-179. [PubMed: 9989257]

Olson JE, Martinho E. Regulation of taurine transport in rat hippocampal neurons by hypo-osmotic swelling. Journal of Neurochemistry. 2006a; 96:1375-1389. [PubMed: 16478528]

Olson JE, Martinho E. Taurine transporter regulation in hippocampal neurons. Adv Exp Med Biol. 2006b; 583:307-314. [PubMed: 17153615]

Pasantes-Morales H, Franco R, Ordaz B, Ochoa LD. Mechanisms counteracting swelling in brain cells during hyponatremia. Arch Med Res. 2002; 33:237-244. [PubMed: 12031627]

Pow DV, Sullivan R, Reye P, Hermanussen S. Localization of taurine transporters, taurine, and ${ }^{3} \mathrm{H}$ taurine accumulation in the rat retina, pituitary, and brain. Glia. 2002; 37:153-168. [PubMed: 11754213]

Sanchez-Olea R, Moran J, Schousboe A, Pasantes-Morales H. Hyposmolarity-activated fluxes of taurine in astrocytes are mediated by diffusion. Neurosci Lett. 1991; 130:233-236. [PubMed: 1795889] 
Schousboe A, Fosmark H, Svenneby G. Taurine uptake in astrocytes cultured from dissociated mouse brain hemispheres. Brain Res. 1976; 116:158-164. [PubMed: 974765]

Schousboe A, Sanchez Olea R, Moran J, Pasantes-Morales H. Hyposmolarity-induced taurine release in cerebellar granule cells is associated with diffusion and not with high-affinity transport. J Neurosci Res. 1991; 30:661-665. [PubMed: 1787540]

Shennan DB. Swelling-induced taurine transport: relationship with chloride channels, anionexchangers and other swelling-activated transport pathways. Cell Physiol Biochem. 2008; 21:1528. [PubMed: 18209468]

Smith KE, Borden LA, Wang C-HD, Hartig PR, Branchek TA, Weinshank RL. Cloning and expression of a high affinity taurine transporter from rat brain. Mol Pharmacol. 1992; 42:563-569. [PubMed: 1435737]

Tuz K, Pena-Segura C, Franco R, Pasantes-Morales H. Depolarization, exocytosis and amino acid release evoked by hypoosmolarity from cortical synaptosomes. Eur J Neurosci. 2004; 19:916-924. [PubMed: 15009139]

Tuz K, Pasantes-Morales H. Hypoosmolarity evokes norepinephrine efflux from synaptosomes via a depolarization and $\mathrm{Ca}^{2+}$-dependent exocytotic mechanism. Eur J Neurosci. 2005; 22:1636-1642. [PubMed: 16197504]

Vazquez-Juarez E, Ramos-Mandujano G, Hernandez-Benitez R, Pasantes-Morales H. On the role of G-protein coupled receptors in cell volume regulation. Cell Physiol Biochem. 2008a; 21:1-14. [PubMed: 18209467] 


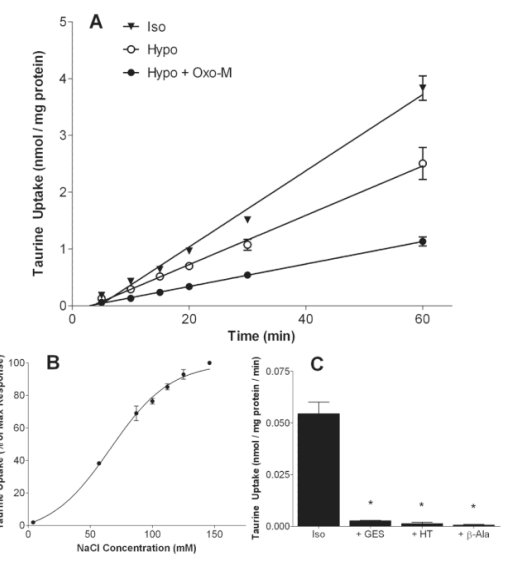

Fig. 1.

Kinetics and characteristics of taurine uptake in SH-SY5Y cells. (A) Cells were washed once with $2 \mathrm{ml}$ of isotonic buffer prior to incubation in $5 \mathrm{ml}$ of either isotonic $(340 \mathrm{mOsM}$; $\boldsymbol{\nabla})$ or hypotonic $(230 \mathrm{mOsM})$ buffer that contained $0.8 \mu \mathrm{Ci}{ }^{3} \mathrm{H}$-taurine and $5 \mu \mathrm{M}$ unlabeled taurine in the absence $(\circ)$ or presence $(\bullet)$ of $100 \mu \mathrm{M}$ Oxo-M. Reactions were terminated at the times indicated and ${ }^{3} \mathrm{H}$-taurine uptake was monitored. Results are expressed as taurine influx (nmol/mg protein/min) and are the means \pm SEM of 3 independent experiments, each performed in triplicate. Where error bars are absent the SEM fell within the symbol. Rates of taurine influx were calculated from linear regression analyses of the data. (B) Cells were incubated for $10 \mathrm{~min}$ in $5 \mathrm{~mL}$ of isotonic buffer containing $\mathrm{NaCl}$ at the concentrations indicated (osmolarities were adjusted to $340 \mathrm{mOsM}$ by the addition of sucrose). Results for taurine uptake are expressed as percent of maximum response obtained at $142 \mathrm{mM} \mathrm{NaCl}$ $(0.06 \pm 0.01 \mathrm{nmol} / \mathrm{mg}$ protein $/ \mathrm{min})$ and are the means $\pm \mathrm{SEM}$ of 3 independent experiments. Where error bars are absent the SEM fell within the symbol. (C) Taurine uptake was monitored under isotonic conditions (Iso) in the absence or presence of $1 \mathrm{mM}$ concentrations of GES, hypotaurine (HT) or $\beta$-alanine ( $\beta$-Ala). Results for taurine uptake, expressed as $\mathrm{nmol} / \mathrm{mg}$ protein/min, are means \pm SEM for 3 independent experiments. *, Different from Iso, $\mathrm{p}<0.01$ (by repeated measures ANOVA followed by Dunnett's multiple comparison test). 


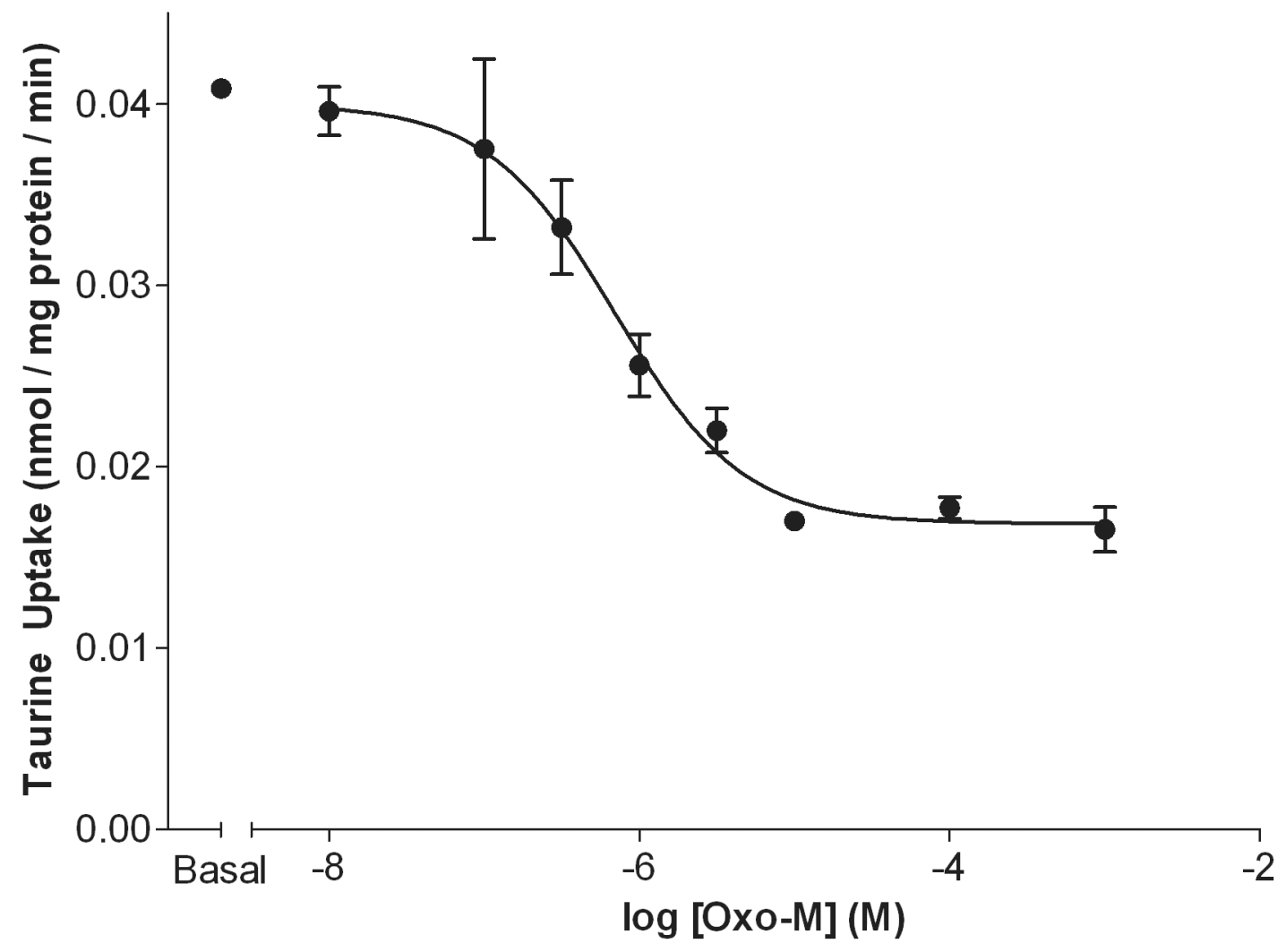

Fig. 2.

Dose-response relationship for Oxo-M-mediated inhibition of taurine influx. SH-SY5Y cells were incubated in $5 \mathrm{~mL}$ of hypotonic buffer $(230 \mathrm{mOsM})$ containing $5 \mu \mathrm{M}$ taurine and Oxo$\mathrm{M}$ at the concentrations indicated. Reactions were terminated after $10 \mathrm{~min}$ and taurine uptake monitored. Results are expressed as taurine influx (nmol/mg protein/min) and are the means \pm SEM of 3 independent experiments. Where error bars are absent the SEM fell within the symbol. Addition of Oxo-M inhibited taurine influx with an $\mathrm{EC}_{50}$ of $0.7 \mu \mathrm{M}$ and with a Hill coefficient of 1.1. 


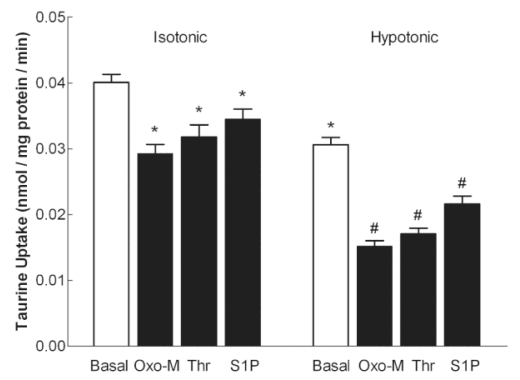

Fig. 3.

Activation of multiple GPCRs can attenuate taurine influx. SH-SY5Y cells were incubated in $5 \mathrm{ml}$ of either isotonic (340 mOsM: A) or hypotonic buffer (230 mOsM: B) in the absence or presence of $100 \mu \mathrm{M}$ Oxo-M, $1.25 \mathrm{nM}$ thrombin (Thr), or $5 \mu \mathrm{M} \mathrm{S1P}$. Reactions were terminated after $10 \mathrm{~min}$ and taurine uptake monitored. Results are expressed as taurine influx (nmol/mg protein $/ \mathrm{min})$ and are the means \pm SEM of 15 independent experiments for Oxo-M and 5 or 9 experiments for thrombin or S1P, respectively, each experiment performed in triplicate. $*, \mathrm{p}<0.05$, different from basal release monitored under isotonic (340 mOsM) conditions (by repeated measures ANOVA followed by Dunnett's multiple comparison test). \#, $\mathrm{p}<0.05$, different from basal release monitored under hypotonic (230 mOsM) conditions (by repeated measures ANOVA followed by Dunnett's multiple comparison test). 
A

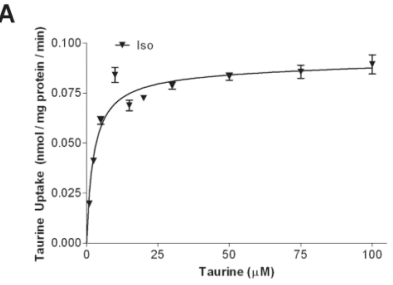

B
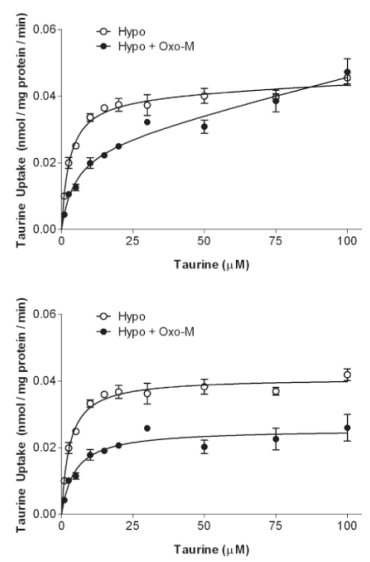

Fig. 4.

Substrate concentration-dependence of taurine uptake. (A) SH-SY5Y cells were incubated in isotonic buffer A (340 mOsM) that contained taurine at the concentrations indicated. (B) SH-SY5Y cells were incubated in hypotonic buffer $(230 \mathrm{mOsM})$ that contained taurine at the concentrations indicated in the absence (open circles) or presence (filled circles) of 100 $\mu \mathrm{M}$ Oxo-M. Reactions were terminated after $10 \mathrm{~min}$ and taurine uptake monitored. Results for both (A) and (B) are expressed as taurine influx (nmol/mg protein/min) and are the means \pm SEM of 3 independent experiments, each performed in triplicate. (C) Plot of taurine influx data obtained from panel $\mathrm{B}$ as a function of taurine concentration following subtraction of the non-saturable, diffusion component (see equation 1 in Material and Methods) 
A

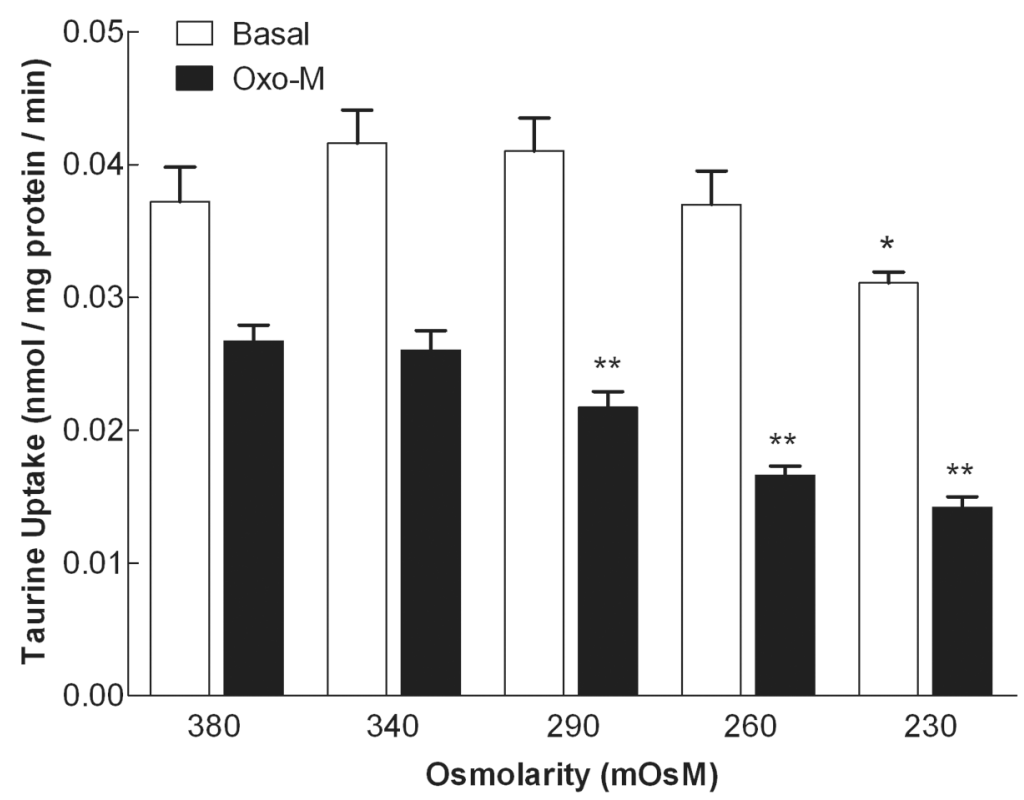

B

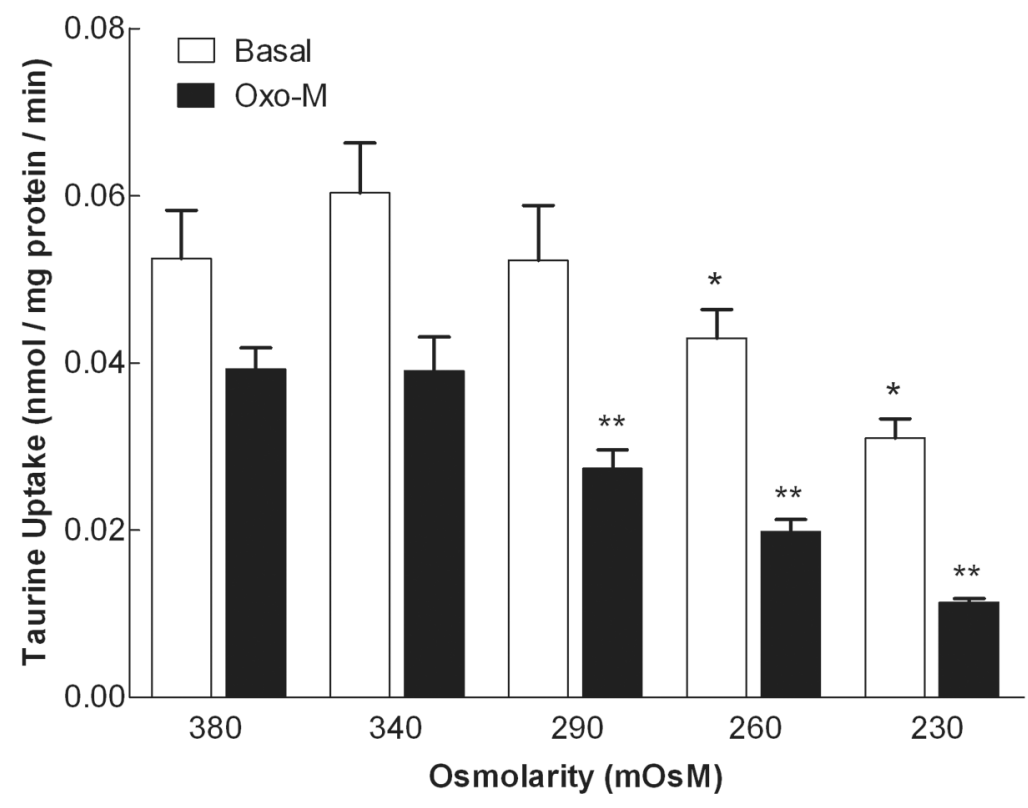

Fig. 5.

Basal- and Oxo-M-stimulated taurine uptake as a function of osmolarity. Taurine influx was monitored during a $10 \mathrm{~min}$ incubation in buffer at the osmolarities indicated in the absence (open bars) or presence (closed bars) of $100 \mu \mathrm{M}$ Oxo-M. (A) Osmolarities of the buffers were adjusted under conditions of a constant $\mathrm{NaCl}$ concentration $(95 \mathrm{mM})$. (B) Buffers were rendered hypertonic or hypotonic by an increase or decrease in $\mathrm{NaCl}$ concentration, respectively. Results are expressed as taurine uptake (nmol/mg protein/min) and are the means \pm SEM of 3-4 independent experiments. *, p $<0.05$, different from basal release monitored under isotonic conditions ( $340 \mathrm{mOsM}$ ) conditions (by repeated measures ANOVA followed by Dunnett's multiple comparison test). **, p < 0.05, different from Oxo- 
M treatment under isotonic (340 mOsM) conditions (by repeated measures ANOVA followed by Dunnett's multiple comparison test). In both (A) and (B), Oxo-M significantly inhibited taurine uptake at all osmolarities when compared with uptake under basal conditions ( $\mathrm{p}<0.01$, by paired Student's $t$ test). 


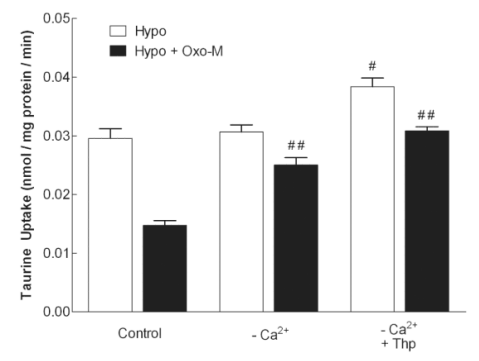

Fig. 6.

The role of extra- and intracellular $\mathrm{Ca}^{2+}$ in basal- and Oxo-M-mediated regulation of taurine influx and efflux. SH-SY5Y cells were incubated in the absence $\left(-\mathrm{Ca}^{2+} ; \mathrm{Ca}^{2+}\right.$ was omitted from buffer and $50 \mu \mathrm{M}$ EGTA was added) or presence of extracellular $\mathrm{Ca}^{2+}$. For some experiments, cells were pre-incubated for $15 \mathrm{~min}$ in isotonic buffer $\mathrm{A}$ in the presence of 1 $\mu \mathrm{M}$ thapsigargin (Thp) to deplete intracellular pools of $\mathrm{Ca}^{2+}$. Cells were then incubated in hypotonic buffer (230 mOsM) in the absence (open bars) or presence (closed bars) of 100 $\mu \mathrm{M}$ Oxo-M. Reactions were terminated after $10 \mathrm{~min}$ and taurine uptake monitored. Results are expressed as taurine influx (nmol/mg protein $/ \mathrm{min}$ ) and are the means \pm SEM of 3-4 independent experiments, each performed in triplicate. \#, $\mathrm{p}<0.05$, different from basal taurine uptake under control conditions (by repeated measures ANOVA followed by Dunnett's multiple comparison test). \#\#, $\mathrm{p}<0.05$, different from taurine uptake monitored in the presence of Oxo-M under basal conditions (by repeated measures ANOVA followed by Dunnett's multiple comparison test). 

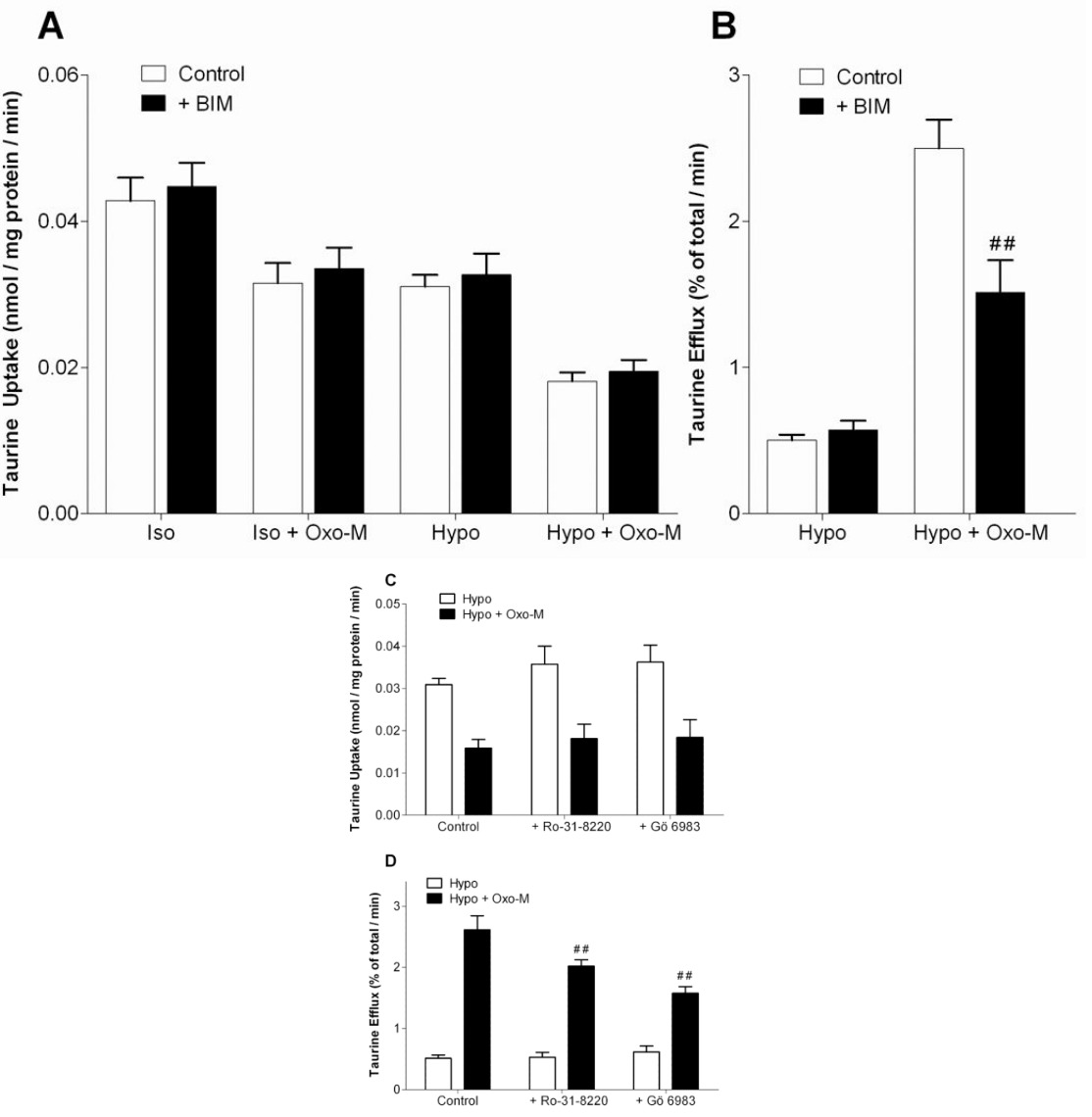

Fig 7.

The role of PKC in basal- and Oxo-M-mediated regulation of taurine influx and efflux. (A) SH-SY5Y cells were first preincubated with a $2.5 \mu \mathrm{M}$ concentration of bisindolylmaleimide in isotonic buffer for $10 \mathrm{~min}$ prior to monitoring taurine uptake under either isotonic (340 $\mathrm{mOsM})$ or hypotonic (230 mOsM) conditions in the presence or absence of $100 \mu \mathrm{M}$ Oxo-M. Reactions were terminated after $10 \mathrm{~min}$ and taurine uptake monitored. Results are expressed as taurine influx ( $\mathrm{nmol} / \mathrm{mg}$ protein $/ \mathrm{min}$ ) and are the means \pm SEM of 3 independent experiments, each performed in triplicate. (B) Cells were treated as described in (A) with the exception that taurine efflux was monitored in cells that had been labeled overnight with $\left[{ }^{3} \mathrm{H}\right]$ taurine. Results are expressed as taurine efflux (percent of total radioactivity initially present in the cells) and are the means \pm S.E.M. of 3 independent experiments, each performed in triplicate. \#\#, $\mathrm{p}<0.01$, different from Hypo + Oxo-M control (by repeated measures ANOVA followed by Dunnett's multiple comparison test). (C) Conditions were as described in (A) with the exception that taurine uptake was monitored following preincubation of the cells with $2.5 \mu \mathrm{M}$ concentrations of either Gö 6983 or Ro-31-8220. Results shown are the means \pm SEM of 3 independent experiments, each performed in triplicate. (D) Taurine efflux was monitored under the conditions described in (B) for cells preincubated with either $2.5 \mu \mathrm{M}$ Gö 6983 or Ro-31-8220. Results shown are the means \pm SEM of 3 independent experiments, each performed in triplicate. \#\#, $p<0.01$, different from Hypo + Oxo-M control (by repeated measures ANOVA followed by Dunnett's multiple comparison test). 


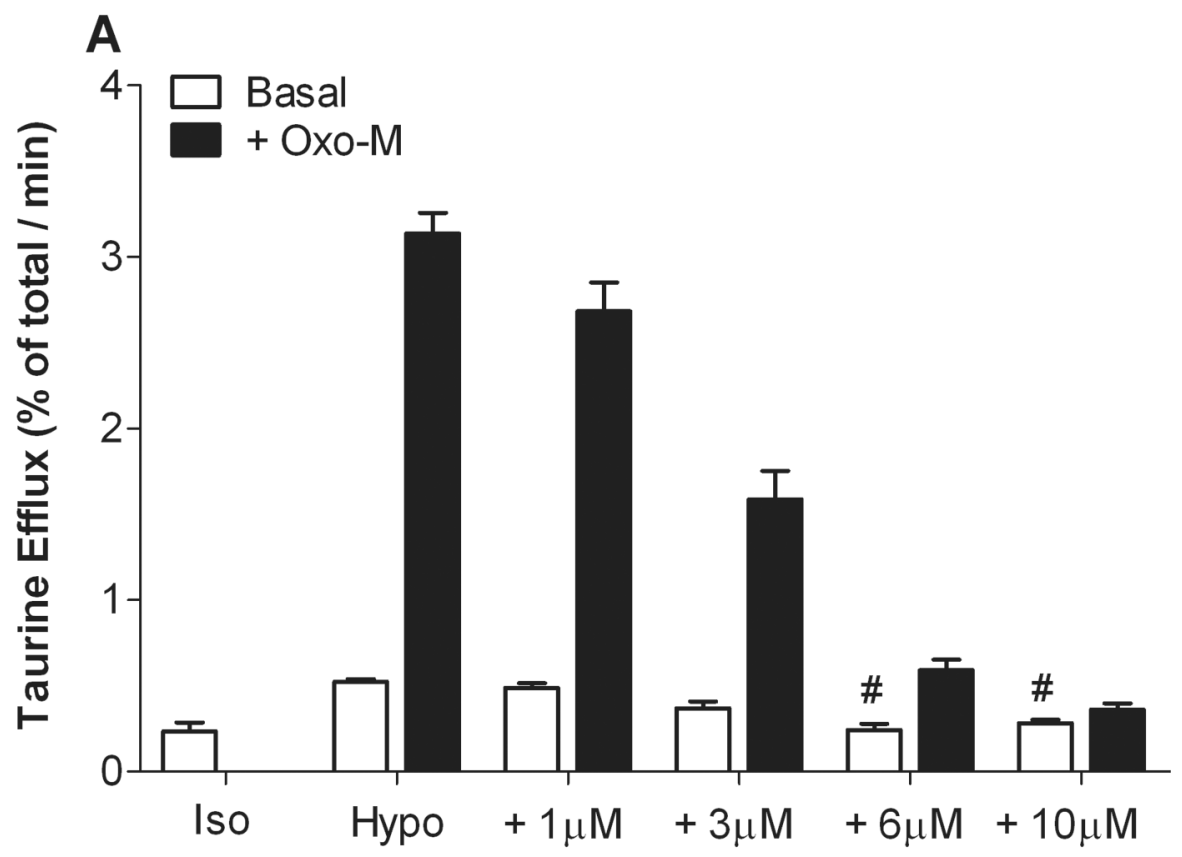

B

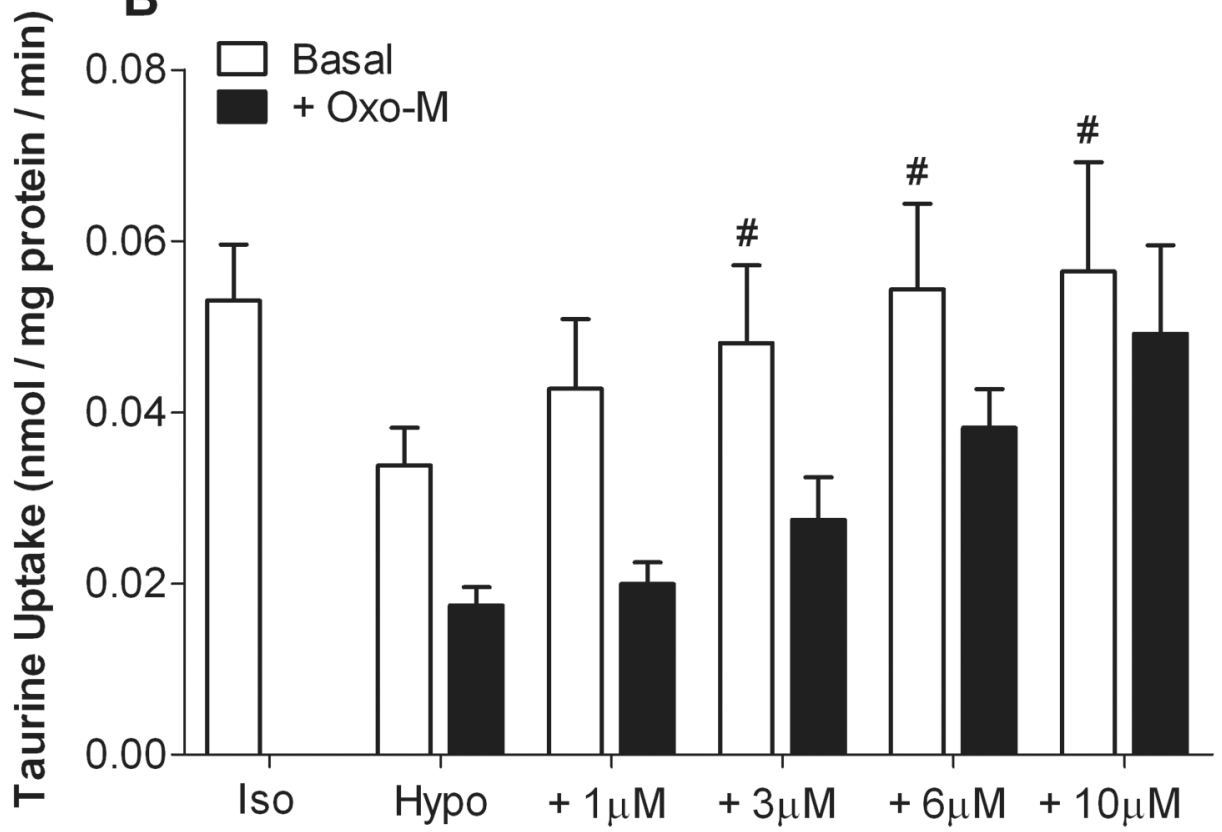

Fig. 8.

DCPIB attenuates both basal- and Oxo-M-mediated changes in taurine efflux and uptake. (A) SH-SY5Y cells that had been labeled overnight with $\left[{ }^{3} \mathrm{H}\right]$ taurine were washed twice with isotonic buffer and then incubated in either isotonic (340 mOsM: Iso) or hypotonic (230 mOsM: Hypo) buffer in either the absence or presence of $100 \mu \mathrm{M}$ Oxo-M (solid bars). To determine the effect of DCPIB, cells were pre-incubated for $10 \mathrm{~min}$ in isotonic buffer in the presence of DCPIB at the concentrations indicated prior to the assay. The buffers were then aspirated and replaced with fresh hypotonic buffer that also contained DCPIB at the concentrations used during the preincubation. (B) Cells were treated as described in (A) with the exception that $\left[{ }^{3} \mathrm{H}\right]$ taurine uptake into unlabeled cells was monitored. For both efflux 
and uptake measurements, reactions were terminated after $10 \mathrm{~min}$ and results expressed as either taurine efflux (percent of total radioactivity initially present in the cells released/min) or, alternatively as taurine influx ( $\mathrm{nmol} / \mathrm{mg}$ protein $/ \mathrm{min}$ ) and are the means \pm S.E.M. of 3-4 independent experiments, each performed in triplicate. \#, $p<0.05$, different from Hypo basal (by repeated measures ANOVA followed by Dunnett's multiple comparison test). At all concentrations of DCPIB, with the exception of $10 \mu \mathrm{M}$, Oxo-M addition significantly increased taurine efflux or attenuated taurine uptake when compared to basal conditions $(\mathrm{p}<0.05$, by paired Student's $t$ test). 


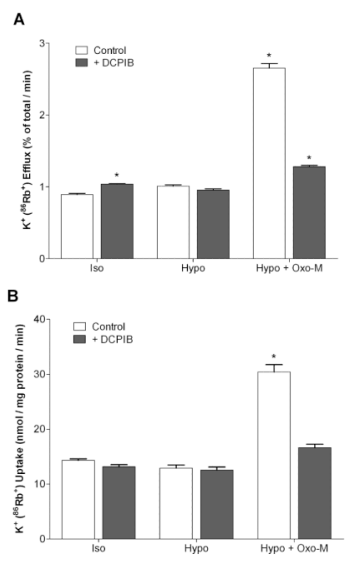

Fig. 9.

DCPIB attenuates both basal- and Oxo-M-mediated changes in ${ }^{86} \mathrm{Rb}^{+}$efflux and uptake. (A) SH-SY5Y cells that had been labeled overnight with ${ }^{86} \mathrm{Rb}^{+}$were washed twice with isotonic buffer and then incubated in isotonic (Iso) or hypotonic (230 mOsM: Hypo) buffer in either the absence or presence of $100 \mu \mathrm{M}$ Oxo-M. To determine the effect of DCPIB (shaded bars), cells were pre-incubated for $10 \mathrm{~min}$ in isotonic buffer in the presence of $10 \mu \mathrm{M}$ DCPIB prior to the assay. The media were then aspirated and replaced with hypotonic buffer that also contained $10 \mu \mathrm{M}$ DCPIB. (B) Cells were treated as described in (A) with the exception that ${ }^{86} \mathrm{Rb}^{+}$uptake into unlabeled cells was monitored. For both efflux and uptake measurements, reactions were terminated after $10 \mathrm{~min}$ and results expressed as either ${ }^{86} \mathrm{Rb}^{+}$ efflux (percent of total radioactivity initially present in the cells released/min) or, alternatively as ${ }^{86} \mathrm{Rb}^{+}$influx (nmol/mg protein/min) and are the means \pm S.E.M. of $4-5$ independent experiments, each performed in triplicate. *, p < 0.05, different from Iso (by repeated measures ANOVA followed by Dunnett's multiple comparison test). 